\title{
Determination of Saponin Compound from Anredera cordifolia (Ten) Steenis Plant (Binahong) to Potential Treatment for Several Diseases
}

\author{
Sri Murni Astuti \\ Faculty of Chemical and Natural Resources Engineering (Bio-Process) \\ Universiti Malaysia Pahang, 26300 Gambang, Kuantan, Pahang, Malaysia \\ E-mail: srimurni.astuti@yahoo.com \\ Mimi Sakinah A.M (Corresponding Author) \\ Faculty of Chemical and Natural Resources Engineering (Bio-Process) \\ Universiti Malaysia Pahang, 26300 Gambang, Kuantan, Pahang, Malaysia \\ Tel: 60-9549-2825Ｅ-mail: mimi@UMP.EDU.MY \\ Retno Andayani B.M \\ Kuliyyah of Pharmacy International Islamic University Malaysia \\ Istana Bandar, Indra Mahkota, 25200, Kuantan, Pahang, Malaysia \\ Awalludin Risch \\ Faculty of Chemical and Natural Resources Engineering (Bio-Process) \\ Universiti Malaysia Pahang, 26300 Gambang, Kuantan, Pahang, Malaysia
}

Received: January 13, 2011 Accepted: January 27, 2011 Published: December 1, 2011

doi:10.5539/jas.v3n4p224

URL: http://dx.doi.org/10.5539/jas.v3n4p224

\begin{abstract}
Saponin has various types; it can be bond with glycosides that form soapy lathers when mixed and agitated with water, and have been used to treat diabetes; liver, hepatitis, cardiovascular as high blood pressure, high cholesterol, and physical stress. In this study describe of saponins compound in Binahong, one of medicinal plant investigated from these plant probably contribute to the effectiveness the above plant for treatment several diseases. The sample were dried by oven $\left(60^{\circ} \mathrm{C}\right)$ to be powder and extracted with solvents. After that used qualitative and quantitative test. The result of Binahong plant contains saponins compound on all a part of the Binahong plant, are positive indicate of presence of saponins triterpenoid and steroid. . Moreover crude of saponins substances from Leaves (28.14 \pm 0.22$)$, Stems $(3.65 \pm 011)$ and Tubers $(43.15 \pm 0.10) \mathrm{of} \mathrm{mg} / \mathrm{g}$. The research showed of the Binahong plant, importance of the distribution of determination of saponins compound from plant, has a potential to treatment for several diseases
\end{abstract}

Keyword: Anredera cordifolia (Binahong) Saponin compound, Steroidal, Triterpenoidal

\section{Introduction}

Anredera cordifolia (Ten) Steenis plant (Binahong) of the family Basellaceae is one of medicinal plant that grows very well since long time ago, it has been widely cultivated as an ornamental vine in tropical regions of the world. Binahong plant native plant from Brazil and common names Madeira vine or Mignonette vine (Wagner et.al, 1999). In Indonesia, Binahong plant have not familiar yet, but this plant was necessary food in Vietnam society (Ferri, 2009) and frequently used as vegetables in Taiwan (Mao-Te et. al, 2007). This plant known to have extraordinary healing, and it has consumed over thousands years by the nation of China, Korea, Taiwan (Feri, 2009). Almost all parts of plants such Binahong bulbs, stems and leaves can be used in herbal therapy (Yuswantina, 2009) and (Ferri, 2009). 
Binahong plant contains saponins, alkaloids, polyphenols, flavonoid and mono polysaccharide including L-arabinose, D-galaktose, L-rhamnose, (Rachmawati, 2008),D-glucose are among the most common components of the attached chains (Hosttetman and Marston, 1995) These plant also have high compound of flavonoid from leaves, stems, tubers and flowers (Harborne, 1973), may be efficacious as anti-microbe (Robinson, 1995). As flavonoid has direct roles as antibiotic function have a broad spectrum target (Ferri, 2009). The Binahong leaves has antioxidant activity, ascorbic acid and the highly of phenolic compound (Uchida, 2003), and the compound has the ability against gram-positive and gram-negative bacteria to be more susceptible on the inhibitory effect and used in the treatment of sexuality transmitted diseases (Tshikalange et al, 2005). The leaves also have oleanolic acid content who has anti-inflammatory properties that can reduce pain in burns (Hammond, 2006). The oleanolic acids is contain triterpenoid (Tshikalange et al, 2005), and from tubers it was found the protein content (ancordin) as immune stimulant to stimulate antibody formation (Net wall et.al, 1996) and (Mao-Te et.al, 2007). The proteins can stimulate of nitrite oxide, which can improve the flow of blood carrying nutrients to every tissue cells and stimulates the body to produce growth hormone and reproductive cells replace damaged cells (Mao-Te et.al, 2007).

The classical definition of saponins is based on their surface activity and many saponins have detergent properties, give stable foams in water, show hemolytic activity have better taste (Ceyhun and Artik, 2010). Saponin is one class of compounds glycosides, steroids and their structure and specificity triterpenoid, its has colloidal solutions form in water and foamy like soap, if mixture was shaken (Konoshima et al, 1995)There are describes a group of complex compounds, and the large molecules which have many benefits (Konoshima et al, 1995) and (Burger et al, 1998). Saponin can be found on the roots and leaves of plants (Yongmok. et al, 2009), also as antimicrobial, such as antibacterial and anti viral, the presence of saponins characterized by the existence of a stable colloidal solution (Harborne, 1973). The functions as a cleaner, is able to stimulate the formation of collagen, a protein that plays a role in the process of wound healing (Suratman et al, 1996), more ever, saponins can be classified as steroidal, triterpenoidal or alkaloid depending on nature of aglycone, and aglycone part of a saponins referred to as a sapogenin are generally oligosaccharide (Natori et al, 1981). ). The saponins steroid hormones are steroids that act hormones, can be grouped into five group by the receptor to which they bind, glicocorticoids, mineral corticoids, androgens, estrogens and prostagens, viamin D derivate a sixth, closely related hormone system (Jimmy,2010). Steroid in modern clinical studies have supported their role as anti inflammatory and analgesic agents (Singh, 2006).

The isolated of saponins have shown a variety activities such antitumor, cholesterol lowering, immune potentiating, anticancer, antioxidants (Blumert and Liu, 2003) and to presser lower risk of implicated in coronary heart diseases (Achinrwhu, 1983), and saponins potential as ointment hydrocarbon to shape of first collagen, there is protein have a role in recovery process of wound healing (Isnaini, 2009). Lot of saponins used as the standard properties of traditional medicine, and one of metabolite secondary compound can be finding in medicinal plants.

The benefit of plant, source from the testimony some people in Javanese Indonesia, can treat diabetes mellitus, typhoid, hypertension, hemorrhoids, tuberculosis, rheumatic, uric acid, asthma, to increase urine volume for diuretic, postpartum recovery, wound healing and post-circumcision operating, also colitis, diarrhea, gastritis and cancer.(Ferri, 2009; Rosmalawati, 2010 and Sukandar,2010)

The society in Javanese, Indonesia, trusted, Binahong plant is miracle of plant can be treating of several diseases and make the body health, but Binahong plant is not well documented, and science evidence is limited to establish as a medicinal herbal and very little is known regarding the effect of saponins and bioactive compound in Binahong plant. In the study showed, that Binahong plant contain saponins compound, these plant probably contribute to the effectiveness the above plant in chronic and infectious diseases therapy. The aim of the study here, to determine of saponin compound from Anredera cordifolia (Binahong), which many potential to treat of the various diseases.

The rest of the paper is organized as follow. Section 2 describes material and method of this study which is consist of determination of saponins compound of fresh and dry leaves, tubers, flowers and stems of Anredera cordifolia plant (Binahong) and saponins compound, glycosides, terpenoid, steroids and alkaloids using screening test by qualitative as Thin layer chromatography (TLC) and for determine of saponins used quantitative method with investigated method for $\mathrm{mg} / \mathrm{g}$ dried weight from material of test. And section 3 describes result and discussion of positive indicate of saponins compound from all part of Binahong plant. . Finally the conclusion of this study is described in section 4. 


\section{Materials and Methods}

\subsection{Collection and identification of plant materials}

The leaves, stems, flowers and tubers of Anredera cordifolia plants (Binahong) were collected from EnHa farm, Depok, Jakarta, Indonesia. The plant samples were identified by Herbarium Bogoriense, no: 1022.

\subsection{Materials}

The plant samples were air dried (flowers) and leaves, Stems, tubers by oven $\left(60^{\circ} \mathrm{C}\right)$ ground by blender to be powder. The part of sample extract with distilled water, ethanol and Methanol solvent. Saponin test used fresh and dried sample, chemicals test were carried out on the aqueous extract and on the powder sample using standard procedures to identify the constituent as described by Sofofara (1993) and Harborne (1973).

\subsection{Equipments}

Glassware, blender, soxhklet, mixer, analytical balance, water bath, hot plate, rotary evaporation ,separate funnel, micro pipette, centrifuge oven. and TLC plate

\subsection{Method}

\subsubsection{Saponin Test with dry sample}

0.5 gram of crude powder was shaken with water in a test tube and it was warmed in a water bath, the stable persistent froth, was mixed with 3 drops of olive oil and shaken vigorously, then observed for the formation of emulsion, indicates the presence of saponins (Kapoor et al, 1969; Smolenski et al, 1974 and Edeoga et al,2005).

\subsubsection{Saponin Test with Fresh Sample}

10 gram of fresh sample (Plants), dissolve in $100 \mathrm{ml}$ distilled water $(1: 10)$, to blend, and filtered, the filtrate in the test tube, and it was warmed in water bath, the stable persistent froth, was mixed with 3 drop of olive oil and shaken vigorously, than observed for the formation of emulsion, indicate the presence of saponins (Edeoga et al, 2005), with some modified.

\subsubsection{Glycosides Test}

0.5 gram of crude powder was dissolved in $5 \mathrm{ml}$ of methanol. $10 \mathrm{ml}$ of $50 \% \mathrm{HCl}$ was added to $2 \mathrm{ml}$ of methanolic extract in test tube. The mixture was heated in a boiling water bath for 30 minute. And than $5 \mathrm{ml}$ of Fehling's solution was added and the mixture was boiled for 5 minute, to observe a brick red precipitate as an indication for the presence of glycosides (Harborne, 1973).

\subsubsection{Terpenoid Test (Salkowski test)}

$5 \mathrm{ml}$ of water extract from plant was mixed in $2 \mathrm{ml}$ of chloroform, and concentrated $3 \mathrm{ml} \mathrm{of} \mathrm{H}_{2} \mathrm{SO}_{4}$, and was carefully added to form a layer. A reddish brown coloration of the inter face was formed to show positive result for the presence of terpenoid (Edeoga et al, 2005)

\subsubsection{Steroids Test}

0.5 grams of crude powder was dissolved in $5 \mathrm{ml}$ of methanol. One $\mathrm{ml}$ of the extract was treated with $0.5 \mathrm{ml}$ of acetic acid anhydride and cooled 3 minute in refrigerator. And then mixed with $0.5 \mathrm{ml}$ of chloroform. After that added one $\mathrm{ml}$ for concentrated sulphuric acid, be carefully by means of a pipette. At the separations level of the two liquids a reddish brown ring was formed, as indication of the presence of steroids (Kola wok et al, 2006) and (Majaw and Moirangthem, 2009).

\subsubsection{Alkaloids Test}

0.5 grams of crude powder was defatted with $5 \%$ ethyl ether for 15 minute. The defatted sample was extracted for 20 minute with $5 \mathrm{ml}$ of aqueous HCL on a boiling water bath. The resulting mixture was centrifuged for 10 minute at $3000 \mathrm{rpm}$. One $\mathrm{ml}$ of the filtrate was treated with few drops of Mayer's reagent and second $1 \mathrm{ml}$ with Dragendroff's reagent ad turbidity was observed (Harborne, 1973) and (Trease and Evans, 1996)

\subsubsection{Qualitative separation of Saponins compound (TLC)}

Two gram of powdered from leaves stems and tubers of plant were extracted with $10 \mathrm{ml} 70 \%$ Ethanol by refluxing for 10 minute. The filtrate is condensed enriched with saturated n-butanol and thoroughly mixed. The butanol was retained condensed and used for chromatography. The saponins were separated using chloroform, glacial acetic acid, methanol and water (64: 34:12:8), solvent mixture. The color and values of these spots were recorded by exposing chromatogram to the iodine vapors (Wagner et al, 1996). 


\subsubsection{Determination of Saponin compound (Identification by analytical method)}

The samples were ground and 20 gram of each was put into conical flask and $100 \mathrm{ml}$ of aqueous ethanol were added. The samples were heated over hot in water bath for 4 hours with continuous stirring at about $55^{\circ} \mathrm{C}$.The mixture was filtered and the residue re extract with another $200 \mathrm{ml} 20 \%$ ethanol. the combined extract were reduced to $40 \mathrm{ml}$ over water bath at about $90^{\circ} \mathrm{C}$ temperature was transferred into $250 \mathrm{ml}$ separatory funnel and 20 $\mathrm{ml}$ of diethyl ether was added shaken vigorously. The aqueous layer was recovered while the ether layer was dischard.The purification process was repeated. $60 \mathrm{ml}$ of $\mathrm{n}$-butanol was added. The combined n-butanol extract were washed twice with $10 \mathrm{ml}$ of $5 \%$ aqueous sodium chloride. The remaining solution was heated in a water bath. After evaporation, the samples were dried in the oven to constant weight and the saponins content was calculated. (Edeoga et. al, 2005)

\section{Results and Discussion}

The present study carried out on the Anredera cordifolia plant (Binahong), revealed the presence of medicinally active constituents are saponins, terpenoid, steroid, glycosides and alkaloid. By screening test of saponins from fresh and dried sample of Binahong plant, all the sample, presence positive saponins compound, with showed Stable persistent froth of saponins content from fresh and dry sample (Table 1). The saponins compound including one of phytochemical, screening test of the plant studied showed that leaves, stems, flowers and tubers are positive indicate presence of saponins, were rich in saponins content. Who notes that saponins is one of the active constituents (Edeoga et al, 2005) and they were known to show medicinal plant activities as well as exhibiting physiological activity (Sofowara, 1993)., in figure 1, describe there is is saponins compound in Binahong plant

In figure 2, describe that saponins terpenoid and steroid compound in Binahong plant, the presence of terpenoid in all part of plant, reported by other researchers, and this plant is widely used in herbal medicine (Hayashi et al, 1993) but steroid found in stems and leaves, showed that reaction color are reddish brown interface form, very strong reaction, see arrow in figure.

On screening of Saponin, include are natural group as like unwilling to work and have big molecule and very important for human benefit's.(Konoshima et al, 1995).Saponin have high molecule weight, and in low concentration saponins can be hemolysis of red blood cell and then for activity of antibacterial function (Harborne, 1973).

The positive result of saponins content can find from leaves and tubers of Binahong plant, there substance important to recovery post surgery as anti bacterial, anti fungus and anti viral ,and saponins have a potential to make clean and can be first collagen form, there is protein of recovery and wound recovery post surgery (Hidayati, 2009).

Many saponins are present in higher plants in the form of glycosides of complex alcylic compound and show characteristic foaming properties in aqueous solution, this plant contain little or no saponins, and others plants triterpenoid saponins predominate, are subdivided into 20 groups (Kereru et .al, 2008). The result of Anredera cordifolia plant (Binahong) analyses found glycosides and terpenoid but steroids only found on leaves and stems of plant. Whereas, alkaloid found on leaves, stems and tubers. These investigated plant contained steroidal compound from leaves and stems of Binahong (in table 2) Steroidal compounds are importance and interest in pharmacy due to their relationship with such compounds as sex hormones (Okwu, 2001).

The properties of medicinal plant as Binahong plant are perhaps due to this presence of various secondary metabolites such as alkaloids, glycosides, saponins terpenoid and steroid. Thus the preliminary screening test useful in the detection of the bioactive principles and subsequently may lead to the drug discovery and development (Mallikharjuna et al, 2007).

The Saponin group of glycosides that are glycone and aglycone, and glycone is sugar and aglycone is sapogenin, the group is neutral saponins and acid saponins. Steroid include group of neutral saponins , and triterpenoid from acid saponins (Duke, 1992) On hydrolysis of saponins yield aglycone called sapogenin as cortisone .Saponin based structure namely steroids in plants monocots and triterpenoid in plants dicotyledonous (Puryanto, 2009). The leaves of plant contain saponins compound and an active compound on the surface and acts like gelatin and frothy, extract of saponins compounds will give better results when using a solvent such as ethanol (Harborne, 1973). Some saponins could be inhibiting microorganism as antibacterial and antifungal activity, steroid saponins are common in plant used as herbs or for their health promoting properties (Olezek et al, 1990). Terpenoid is a component of plants that have a smell and can be isolated from vegetable and essential oil and the structure of terpenoid compound from variety of secondary reactions, such as hydrogen, oxidation, reduction, but 
Steroids are the sterols, bile acids, sex hormones, hormone adenocorticoid, aglycone, cardiac, this group determined R1,R2 and R3 (side chains) to the basic framework of carbon (Lenny, 2006). Steroid hormones are steroids that act hormones, can be grouped into five group by the receptor to which they bind, glicocorticoids, mineral corticoids, androgens, estrogens and prostagens, viamin D derivate a sixth, closely related hormone system (Jimmy, 2010).

The classification of terpenoid determinate of unit chains of compound to general biosyntheses arrangement from terpenoid, the group of terpenoid mechanism one of a triterpenoid, the group are 4000 content and haven isolation about 40 compound (Lenny, 2006).Determination of saponins from Anredera cordifolia plant (Binahong), the reason is, leaves and tuber of plant used as vegetable for human health and to cure of diseases. The origin of steroid, biogenetic experiments showed that the wild there is a steroid derived from terpenoid and also present in plant tissue is a triterpenoid sikloartenol after experiencing a series of changes (Lenny, 2006).

The plant terpenoid are used extensively for the aromatic qualities, they play a role in traditional herbal remedies and are under investigation for antibacterial, antineoplastic and other pharmaceutical functions (Jimmy, 2010). Triterpenoid are terpenoid derivatives of triterpens molecules, they may have useful anti cancer properties (Laszcyk, 2010).

In the method of separation by TLC, it has revealed the presence of yellow spot colored saponins, from all parts of the Binahong plant. Saponins are glycosides of both triterpenoid and steroid (Mallikharjuna et al, 2007). In the result, from leaves, stems and tubers, has revealed the presence of positive saponins compound, with yellow spot color.(in table 3). The presences of yellow color from saponins are aglycone (sapogenin) of triterpenoid and steroid from Anredera cordifolia plant (Binahong).

Determine of plant for saponins compound, in studied here quantitative estimation of the percentage crude yield of saponins of the Binahong plant, showed that leaves and tubers large amount of saponins crude, from Anredera cordifolia plant (Binahong) are (28.14 \pm 0.22$)$, Stems (3.65 \pm 011$)$ and Tubers $(43.15 \pm 0.10)$ from $\mathrm{mg} / \mathrm{g}$ material dried sample. The crude can be seen such as a potential source of useful drug in table 4

Saponins in Anredera cordifolia plant as Binahong, exhibit a variety of biological activities, and saponins compound in plants widely used in foods, medicines and cosmetics (Waller and Yamasaki, 1966), in other plants research by Ono et al (1988) and Son and Do (1990), among them, a steroidal saponins is known to have a hypoglycemic activity (Kato and Miura, 1994). In fact, saponins in rhizome of plant species are used for diabetes in folk medicine (Jeong and Jim Wong, 2005) .The Saponin compounds are very important for the role of activities substances in this Binahong plant for the human health, the result of saponins compound from leaves, stem and tubers of Binahong plant, the determine of Saponin in this plant, is domineer compound

\section{Conclusion}

In this study here, the research has successfully show significance of the Binahong plant in traditional medicine has a potential to treat the various diseases. Also importance of the saponins compound distribution from plant, has a potential for treatment several chronic diseases. Saponins compound is very important properties and has many beneficial for human health and the potential source to therapeutically. The Binahong plant, contains saponins on all a part of the plant, there are positive, indicate of presence of saponins triterpenoid, steroid, glycoside and alkaloid found on tubers, leaves and stems . Binahong, one of medicinal plant investigated from leaves, tubers, stems and flowers, these plant probably contribute to the effectiveness the above plant for treatment several diseases. They have been used to treat diabetes; liver ailments such as hepatitis, cardiovascular problems such as high blood pressure, high cholesterol, and blood clots, mental and physical stress. Further studies are going onto analyzed extract other component of plant

\section{References}

Achinrwhu, S, C. (1983). The saponins Content of Some Nigerian Oil Seeds. Qual Plant Foods Human Nutr, 33 : 3-9. http://dx.doi.org/10.1007/BF01093732

Blumert, M and Liu J. (2003). Jiaogulan (Gynostemma pentaphyllum), China's Immortality Herb $3^{\text {rd }}$ ed. Torchlight.

Ceyhun. Sezgin.A.E and N.Artik. (2010). Determination of Saponin content in Turkish Tahini Halvah by using HPLC. Advance Journal of food Science and Technology, 2(2): 109-115.

Duke, J.A. (1992). Handbook of Phytochemical constituents of Grass herb and economic plants. Boca Raton, FL: CRS Press. 
Edeoga. H.O, D.E Okwu and B.O Mbaeble. (2005). Phytochemical Constituents of Some Nigerian Medicinal Plants, African Journal of Biotechnology, Vol.4 (7) pp 685-688.

Ferri Manoi. (2009). Binahong (Anredera cordifolia) Sebagai Obat. Bulletin Warta Volume 15, Number 1, April 2009. Penelitian dan Pengembangan Tanaman Industri. Badan Penelitian dan Pengembangan Pertanian. Pusat Penelitian dan Pengembangan Perkebunan, Indonesia.

Hammond G.B. (2006). In Vivo Wound-Healing Activity of Oleanolic Acid Derived from the Acid Hydrolysis of Anredera diffuse. The Guardian, America.

Harborne. J.B. (1973). Phytochemical Method, London, Chapman and Hall, Ltd. Pp 49-188.

Hayashi.T, Okamuka.K, Kawasaki. M and Morita.N. (1993). Production of Diterpenoids by cultured cells from two chemotypes scorparia dulcis Phytochemistry, 35 (2):353-356. http://dx.doi.org/10.1016/0031-9422(93)85516-T

Hidayati Isnaini. (2009). Uji Aktivitas Salep Extract Daun Binahong (Anredera cordifolia(Ten) Steenis) Sebagai Penyembuhan luka Bakar Pada Kulit Punggung Kelinci. Skripsi Fakultas Farmasi, Universitas Muhammadiyah Surakarta. Indonesia.

Jimmy Wales. (2010). A personal appeal for Wikipedia founder. En.wikipedia.org/wiki/terpenoid.

Kan. W.S. (1986). Pharmaceutical botany, National Research Institute of Chinese Medicine, Taipei pp. 447.

Kapoor L.D, Singh. A, Kapoor.S.L and Shrivastava S.N. (1969). Survey of Indian medicinal plants for saponin, alkaloid and Flavonoids. Lloyd, 32:297-302.

Kareru PG, Keriko LM, Gachanja AN and Kenji, GM. (2008). Direct detection of Triterpenoid Saponin in Medicinal Plants, Afr, J, Trad., CAM (0000)5(1):56-60.

Kato, A. and Miura, T. (1993). Hypoglycemic activity of Polygonatirhizoma in normal and diabetic mice. Biol. Pharm. Bull., 16, 1118-1120. http://dx.doi.org/10.1248/bpb.16.1118

Kolawole O.M, Ogutoye.S.O, Agbede.O and Olayemi A.B. (2006). Studies on the efficacy of Bridelia ferruginea Benth. Bark extract in reducing the coli form load and BOD of domestic waste water. Etnobotanical Leaflets, 10, 228-238.

Konoshima, Yasudo.T, Kashiwada.Y, Cosentino,L and L.K.Hsiung. (1995). Anti aids agents, 21 triterpenoid saponins as anti HIV principles from fruits of Gleditsia japonica and gymnocladus chine sis, and a structure activity correlation, J Nat Prod, 58(9): 1372-1377. http://dx.doi.org/10.1021/np50123a006

Laszcyk.M.N. (2010). Pentacyclae intervenes of the lupine, oleaname and instant group as tools in cancer therapy.

Lenny Sovia. (2006). Senyawa Terpenoid dan Steroid. Department Kimia, Fakultas Mathematic dan ilmu Pengetahuan alam. Universitas Sumatra Utara, Medan.

Majaw.S and J.Moirangthem. (2009). Qualitative and Quantitative Analysis of Clerodendron colebrookkianum Walp. Leaves and Zingiber cassumurnar Roxb. Rhizomes, Department of Biotechnology and Bioinformatics, North Eastern Hill University, Meghalaya, India.

Mallikharjuna.P,B. Rajana.L.N, Seetharam,Y.N and Sharanabasappa.G.K. (2007). Phytochemical Studies of Strychnos potatorum L.F-A Medicinal Plant. E-Journal of Chemistry, vol4, No4, pp.510-518

Mao-Te Chuang, Yin Shiou Lin and Wen-Chi Hou. (2007). Ancordin, the major rhizome protein of Madeira-vine, with trypsin inhibitory and stimulatory activities in nitric oxide productions. Peptide, Volume 28, Issue 6, June 2007, Pages 1311 - 1316. Elsevier Inc.

Mi-Jeong Anh and Jim Wong Kim. (2005). Identification and Qualification of steroidal saponins in polygonatum species by HPLC/ESI/MS. Arch. Pharm. Res., Vol 28, No 5, 592-597. http://dx.doi.org/10.1007/BF02977764

Natori S, Ikekawa, Nand Suzuki. (1981). Advances in Natural Product Chemistry: ctraction and Isolation of Biologically Active compound, Kadansha Ltd, Tokyo 12, Japan, pp275-287.

Net wall C.A, Anderson L.A and Philip son J.D. (1996). Herbal Medicine: A guide for health care professional. The Pharmaceutical Press. London.

Obadoni BO and Ochuko PO. (2001). Phytochemical Studies and Comparative Efficacy of the crude extracts of Some Homeostatic plant in Edo and Delta State of Nigeria, Global J. Pure Appl. Sci, 8 b: 203-208. 
Okwu.D.E. (2001). Evaluation of the chemical composition of indigenous spices and flavoring agents. Global J.Pure Appall Si., 7 (3): 455-459.

Olezek,, Price KR, Colquhoun, IJ, Jurizta, M, Ploszynski, M and Fenwick, GR. (1990). Isolation and Identification of Alfalfa (Mediego sativa L) root saponins; their activity in relation to a fungal bioassay. $J$ Agric, Food chem., 38: 1810-1817.

Ono. M., Shoyama, K., and Nohara, T. (1988). The constituents of Chinese Polygonati Officinalis Rhizome and PolygonatiRhizoma. Shoyakugaku Zasshi, 42, 135-142

Puryanto. (2009). Uji Aktivitas Gel Ekstrak Ethanol Daun Binahong (Anredera cordifolia (Tenore) Steen) Sebagai Penyembuh Luka Bakar Pada Kulit Punggung Kelinci., Skripsi Fakultas Farmasi Universitas Muhammadiyah Surakarta. Indonesia.

Rachmawati S, (2008). Study Macroscopic, dan Skrining Fitokimia Daun Anredera cordifolia (Ten) Steenis. Airlangga University. Indonesia.

Robinson's. (1995). Kandungan organicTumbuhan tinggi diterjemahkan Padnawinata K, Edisi ke-6 Institute Technology Bandung, Bandung 193.

Rosmalawati.S. Khaerunisa, E. Sandra, Suparjo, J.I.Royani and T.Tajuddin. (2010). Effect of Various Cytokine on Shoot Multiplication and Growth of Binahong (Anredera cordifolia(Ten)Steenis Proceeding $38^{\text {th }}$ Meeting of National Working Group, International Conference on Medicinal Plants Surabaya, 21-22 July 2010, Indonesia.

Singh A, P. (2006). Short review: Distribution of steroid like Compound in Plant Flora. Pgarmacognosy magazine, 2(6):87-89.

Smolenski S.J, Silinis.H and Franswoth. N.R. (1974). Alkaloids screening V.Lloydia, 37, 506-536.

Sofofara .A. (1993). Medicinal Plant and Traditional medicine in Africa Spectrum Book Ltd, Ibadan, Nigeria. 289.

Son, K. H. and Do, J. C. (1990). Steroidal saponins from the rhizomes of Polygonatum sibiricum. J. Nat. Prod., 53, 333-339. http://dx.doi.org/10.1021/np50068a010

Sukandar E.Y, A.B.Sutjiatmo and N.P.Sari. (2010). Diuretic Effect of Ethanol Extract of Anredera cordifolia (Ten) V.Steenis in Westar Rat. Proceeding $38^{\text {th }}$ Meeting of National Working Group, International conference on Medicinal Plants Surabaya 21-22 July, 2010, Indonesia.

Suratman. (1996). In Isnaini Wahyu Hidayati (2009). Uji Aktivitas Salep Ekstrak Daun Binahong (Anredera cordifolia (Ten.) Steenis) Sebagai Penyembuh Luka Bakar pada Kulit Punggung Kelinci. Skripsi Fakultas Farmasi Universitas Muhammadiyah Surakarta. Indonesia.

Trease G.E and Evans W.C. (1996). A text book of Pharmacognosy, $14^{\text {th }}$ ed, Bailliere Tindal Ltd, London,pp 832.

Tshikalange T.E, JJM. Meyer and AA.Husein. (2005). Antimicrobial activity, toxicity and the isolation of a bioactive compound from plants used to treat sexually transmitted diseases, Journal of Ethno pharmacology, 96, pp 515-519. http://dx.doi.org/10.1016/j.jep.2004.09.057

Uchida.S. (2003). Production of Digital map of the Hazardous Condition of Soil Erosion for the Sloping Lands of west Java, Indonesia, using Geographic Information System (GIS) JIRCAS, Indonesia.

Wagner, W.L., D.R. Herbst, and S.H. Sohmer. (1999). Manual of the Flowering Plants of Hawai'i. 2 vols. Bishop Museum Special Publication 83. University of Hawaii Press and Bishop Museum Press, Honolulu, HI.

Wagner R and Bladt.S. (1996). Plant Drug Analysis, A Thin layer Chromatography, Atlas $2^{\text {nd }}$ Ed: Springer; Berlin.

Waller, G. R. and Yamasaki, K. Eds.a. (1996). Saponins used in food and agriculture, In Advances in Experimental Medicine and Biology, Vol. 405, Plenum Press, New York.

Waller, G. R. and Yamasaki, K. Eds.b. (1996). Saponins used in traditional and modern medicine, In Advances in Experimental Medicine and Biology, Vol. 404, Plenum Press, New York

Wardani .D, P, Solichatun and A.D Setyawan. (2004). Pertumbuhan dan Produksi Saponin Kultur Kalus Talinum paniculatum Gaertin pada variasi penambahan asam 2,4 Diklorofenoksi Acetate (2,4D) dan Kinetin, Biofarmasi 2 (1):35-43. ISSN: 1693-2242. 
Yongmok Kim and Daniel J.W. (2009). Determination of Saponin and Various Chemical Compound In Camellia sinensis and Genus Ilex, senses Technical (SEN-TN-0027), Hamilton, OH 45011.

Yuswantina Richa. (2009). Uji Aktivitas Penangkap Radical dari Ekstrak Petroleum Ether, Etil, Acetate dan Ethanol, Rhizome Binahong (Anredera cordifolia (Tenore) Steen) dengan Metode DPPH (2,2-difenil-1-1picrilhidrazil). Skripsi Fakultas Farmasi. Universitas Muhammadiyah Surakarta, Indonesia.

\section{Appendix:}

Table 1. Screening of saponins compound on Anredera cordifolia plant (Binahong)

\begin{tabular}{|c|c|c|c|}
\hline No & sample of Binahong plant & Fresh sample & Dried sample \\
\hline 1 & Leaves & + (positive) & + (positive) \\
\hline 2 & Stems & $+($ positive $)$ & $+($ positive $)$ \\
\hline 3 & Flowers & $+($ positive $)$ & $+($ positive $)$ \\
\hline 4 & Tubers & $+($ positive $)$ & $+($ positive $)$ \\
\hline
\end{tabular}

Positive $(+)$ indicate the presence of saponins

Table 2. Qualitative analysis some Phytochemical from Anredera cordifolia plant (Binahong)

\begin{tabular}{|l|l|l|l|l|l|}
\hline No & sample of Binahong plant & Terpenoid & Steroid & Glycosides & Alkaloids \\
\hline 1 & Leaves & positive & positive & positive & positive \\
\hline 2 & Stems & positive & positive & positive & positive \\
\hline 3 & Tubers & positive & negative & positive & positive \\
\hline 4 & Flowers & positive & negative & positive & Negative \\
\hline
\end{tabular}

* $(+)$ positive indicate the presence of constituents and (-) indicate the absence of constituents

Table 3. Qualitative separation of saponins from Anredera cordifolia plant (Binahong)

\begin{tabular}{|l|l|l|l|}
\hline No & Sample of plant & color of the spot & Result \\
\hline 1 & Leaves & yellow & Positive saponins compound \\
\hline 2 & Stems & yellow & Positive saponins compound \\
\hline 3 & Tubers & yellow & Positive saponins compound \\
\hline
\end{tabular}

*Spot yellow color is positive saponin compound

Table 4. Determination of saponins (percentage crude) on the Anredera cordifolia (Binahong) investigated

\begin{tabular}{|l|l|l|l|}
\hline No & Sample of Binahong plant & \multicolumn{1}{|c|}{ Saponin (\%) } & Remark \\
\hline 1 & Leaves of Binahong & $28.14 \pm 0.22$ & Saponin content mg/g (dry weight material) \\
\hline 2 & Stems of Binahong & $3.65 \quad \pm 0.11$ & Saponin content $\mathrm{mg} / \mathrm{g}$ (dry weight material) \\
\hline 3 & Tubers of Binahong & $43.15 \pm 0.10$ & Saponin content $\mathrm{mg} / \mathrm{g}$ (dry weight material) \\
\hline
\end{tabular}

*Crude percentage of saponin from $20 \mathrm{mg}$ dried sample of Binahong plant 


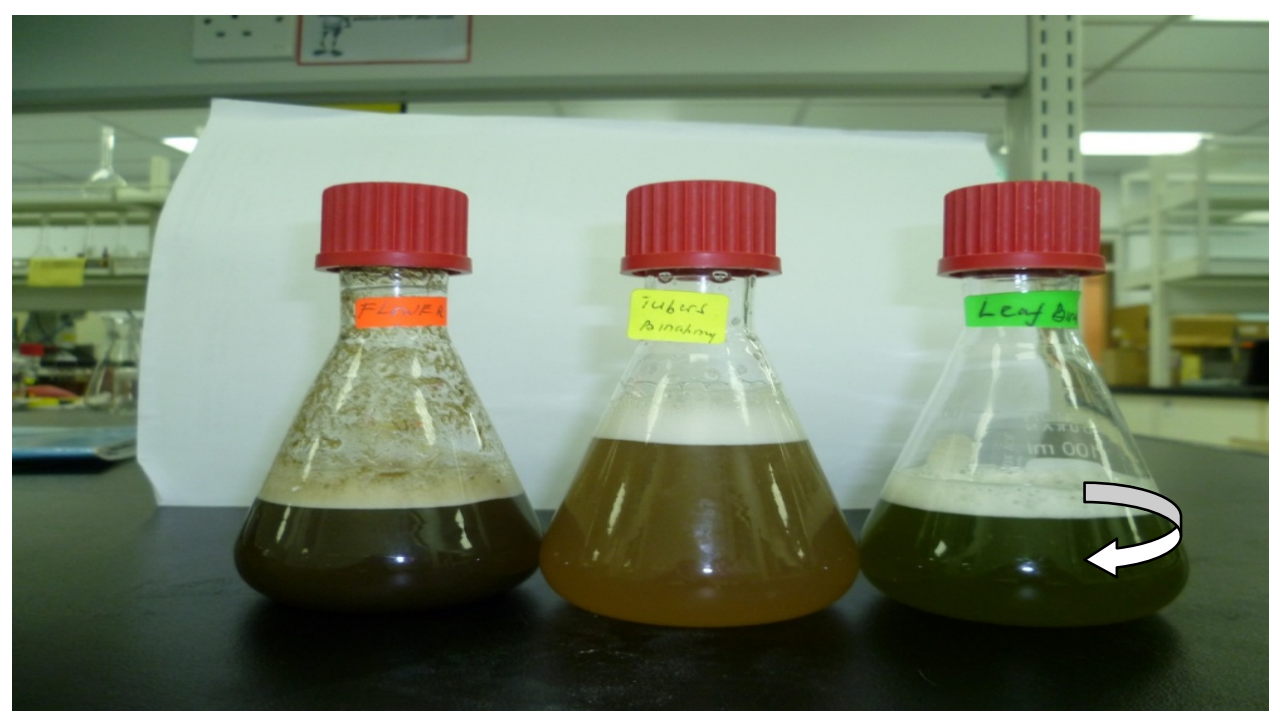

Figure 1. Saponin

Stable persistent froth of saponins content from fresh and dry sample

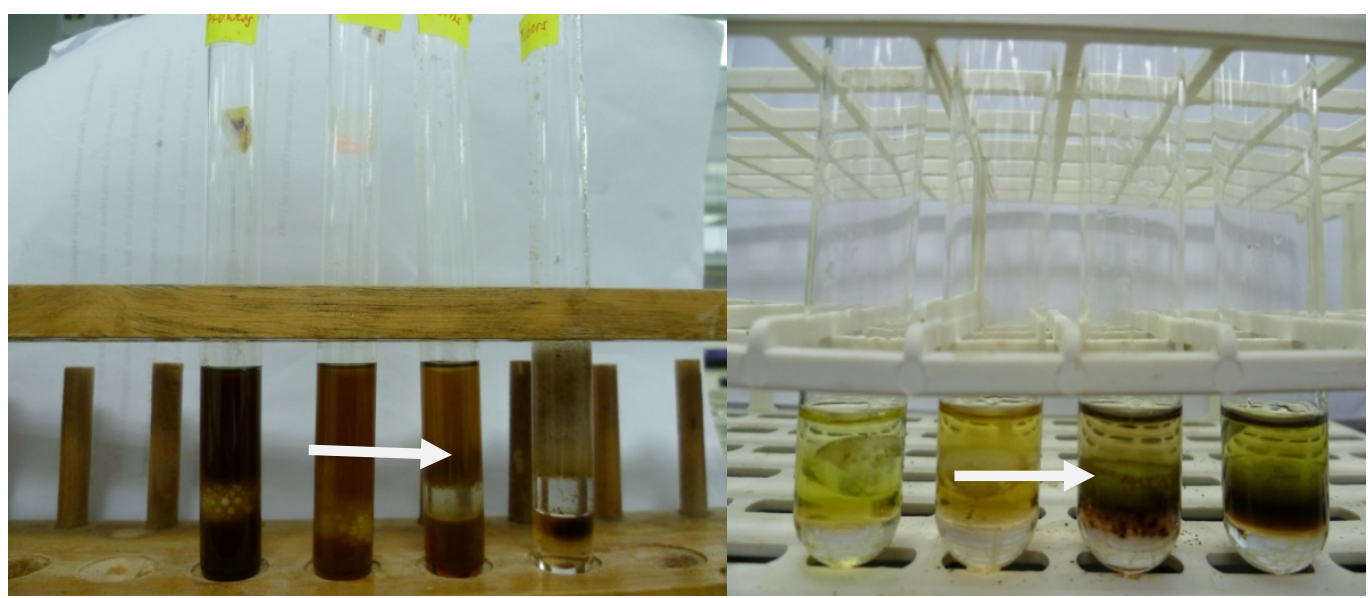

Figure 2. Terpenoid and steroid

Reddish brown coloration interface form terpenoid and steroid

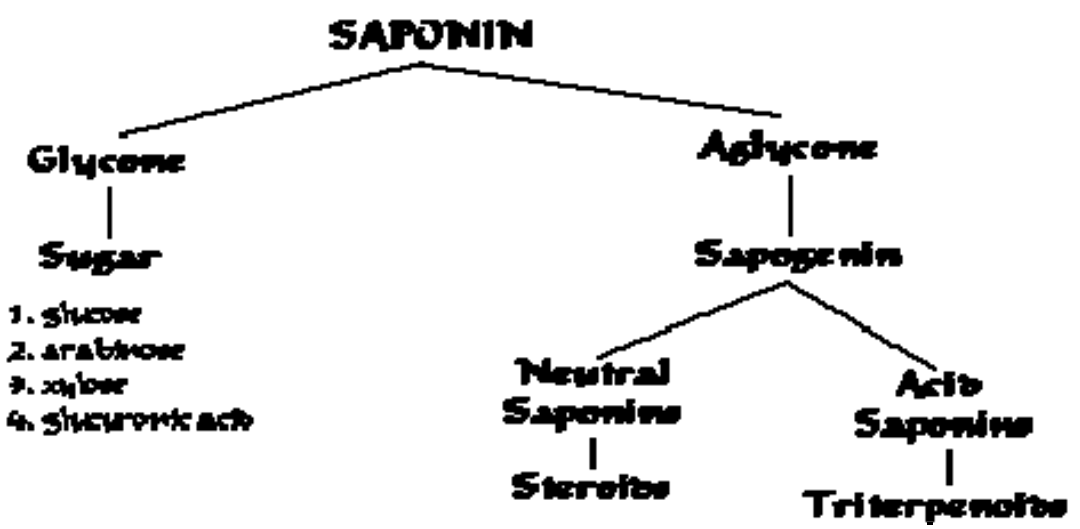

Figure 3. Structure of saponin compound (Duke, 1992)

The acid Saponin process triterpenoid structures 